\title{
PRINSIP KESYARIAHAN DALAM PEMBIAYAAN SYARIAH
}

\author{
Maltuf Fitri
}

\begin{abstract}
Abstrak
Perkembangan perbankan syariah dalam periode tahun 2007-2013 terus menunjukkan kinerja yang menakjubkan. Berbagai indikator kenangan seperti total nilai aset dan jumlah dana pihak ketiga yang berhasil dibimpun terus mengalami peningkatan. Begitu juga dengan tingkat kinerjanya yang digambarkan dari perolehan laba yang dibukukan oleh perbankan dan unit-unit pembiayaan syariab juga mengalami pertumbuban yang positif. Menggeliatnya kegiatan perbankan syariah di Indonesia tidak terlepas dari meningkatnya tingkat kepercayaan masyarakat untuk mengakses jasa layanan perbankan syariah. Hal ini setidaknya juga dapat digambarkan dari keberadaan kantor perbankan syariah dan unit-unit pembiayaan syariah yang tersebar di hampir seluruh wilayah tanah air hingga ke pelosok. Dibandingkan dengan perbankan konvensional, praktek perbankan syariah memiliki perbedaan yang sangat mendasar yaitu tidak menempatkan uang sebagai komoditas perdagangan, penetapan suku bunga dalam transaksi perbankan sangat dilarang karena riba, tidak ada unsur time-value of money dan balas jasa atas penggunaan dana menerapkan prinsip bagi hasil. Untuk memberikan edukasi dan perlindungan kepada nasabah (masyarakat) perlu adanya analisa prinsip-prinsip kesyariaban pada praktek perbankan syariah.
\end{abstract}

Kata Kunci : Perbankan Syariah, Prinsip Syariah, Bagi Hasil, Riba

\section{Pendahuluan}

Dinamika kegiatan pembiayaan berbasis syariah di Indonesia terus menunjukkan perkembangan yang sangat signifikan. Berdasarkan data Bank Indonesia, jumlah jaringan kantor perbankan dan unit-unit pembiayaan syariah selama periode tahun 2007 hingga tahun 2013 mengalami pertumbuhan yang menakjubkan. Pada tahun 2007, jumlah kantor perbankan dan unit-unit pembiayaan syariah sebanyak 782 kantor, dan tahun 2013 telah bertambah menjadi 2.990 kantor. Indikator lain yang juga patut dicermati adalah 
Prinsip Kesyari'ahan dalam Pembiayaan Syariah

pertumbuhan dana pihak ketiganya. Pada tahun 2007, nilai outstanding dana pihak ketiga (DPK) perbankan dan unit-unit pembiayaan syariah sebesar Rp 28.012 miliar, kemudian hingga tahun 2013 telah mencapai sebesar Rp. 183.534 miliar. Secara akuntansi peningkatan DPK ini akan berimplikasi pada total nilai asetnya, dan seperti dalam perkembangan DPK, total asset perbankan dan unit-unit pembiayaan syariah di Indonesia juga tumbuh cukup tinggi. Pada tahun 2007, total nilai aset perbankan dan unit-unit pembiayaan syariah sebesar Rp 36.538 miliar, dan tahun 2013 telah berubah menjadi sebesar Rp. 242.276 miliar.

Dari sisi operasional, meskipun mengalami siklus yang fluktuatif namun secara keseluruhan selama periode yang sama kinerja perbankan dan unit-unit pembiayaan syariah di Indonesia tiap tahunnya terus membukukan laba yang signifikan serta mengalami pertumbuhan laba positif. Pada tahun 2007 perolehan laba yang berhasil dibukukan perbankan dan unit-unit pembiayaan syariah sebesar Rp 540 miliar. Perolehan laba ini memang bisa dikatakan masih relatif kecil bila dibandingkan dengan jumlah lembaganya. Tetapi seiring meningkatnya kepercayaan masyarakat kepada lembaga keuangan berbasis syariah, laba yang berhasil dibukukan perbankan dan unit-unit pembiayaan syariah hingga tahun 2013 telah mencapai sebesar Rp 3.278 miliar.

Tabel 1

Perkembangan Jumlah Kantor dan Indikator Keuangan Perbankan dan Unit Usaha SyariahTahun 2007- Agustus 2013 (BI:2014)

\begin{tabular}{|l|c|c|c|c|c|c|c|}
\hline \multicolumn{1}{|c|}{ Keterangan } & $\mathbf{2 0 0 7}$ & $\mathbf{2 0 0 8}$ & $\mathbf{2 0 0 9}$ & $\mathbf{2 0 1 0}$ & $\mathbf{2 0 1 1}$ & $\mathbf{2 0 1 2}$ & $\mathbf{2 0 1 3}$ \\
\hline Kantor (Unit) & 782 & 1.024 & 1.223 & 1.763 & 2.101 & 2.610 & 2.990 \\
\hline $\begin{array}{l}\text { Dana Pihak Ketiga } \\
\text { (miliar Rp) }\end{array}$ & 28.012 & 36.852 & 52.271 & 76.036 & 115.415 & 147.512 & 183.534 \\
\hline Laba (miliar Rp) & 540 & 432 & 791 & 1.051 & 1.475 & 2.541 & 3.278 \\
\hline Total Aset (miliar Rp) & 36.538 & 49.555 & 66.090 & 97.519 & 145.467 & 195.018 & 242.276 \\
\hline
\end{tabular}

Sumber :Statistik Perbankan Syariah - Bank Indonesia.

Apabila mencermati ilustrasi data-data indikator di atas, maka cukup jelas geliat potensi pasar pembiayaan syariah di Indonesia memiliki peluang untuk terus tumbuh. Atau bila ditarik lebih jauh dalam pengertian derivatif dari 
perspektif dua pihak yaitu masyarakat selaku pengguna jasa layanan dan industri keuangan syariah selaku pelaku operatornya maka peningkatan permintaan jasa layanan keuangan syariah (pasar) akan direspon perbankan dan unit-unit pembiayaan sya'riah dengan terus menambah unit-unit layanannya (pelaku pasar).

Begitu dinamisnya perkembangan industri perbankan syariah di Indonesia terdapat beberapa faktor pendorong yang mendukungnya, salah satu faktor pendorong tersebut menurut Deputi Gubernur Bank Indonesia, Halim Alasmsyah, adalah adanya beberapa produk perundangan yang memberikan kepastian hukum dan meningkatkan aktivitas pasar keuangan syariah, seperti: (i) UU No.21 tahun 2008 tentang Perbankan Syariah; (ii) UU No.19 tahun 2008 tentang Surat Berharga syariah Negara (sukuk); dan (iii) UU No. 42 tahun 2009 tentang Amandemen Ketiga UU No.8 tahun 1983 tentang PPN Barang dan Jasa. Lahirnya UU Perbankan syariah mendorong peningkatan jumlah BUS dari sebanyak 5 BUS menjadi 11 BUS dalam kurun waktu kurang dari dua tahun (2009-2010). ${ }^{1}$

Dengan semakin besarnya perhatian dan dukungan pemerintah terhadap perkembangan lembaga keuangan syariah maka bukan tidak mungkin lembaga keuangan syariah tidak hanya sekedar menjadi pilihan alternatif bagi masyarakat yang membutuhkan layanan perbankan atau pembiayaan berbasis syariah tetapi dapat menjadi pilihan utama. Pendapat ini bukan tanpa dasar mengingat Indonesia merupakan negara dengan jumlah penduduk muslim terbesar di dunia.

Namun terlepas dari argumentasi tersebut, apabila mencermati pola perkembangan yang terjadi sampai saat ini dimana keberadaan lembaga keuangan syariah begitu banyak jumlahnya dalam berbagai skala tingkatan pelayanan dan hampir tersebar di semua wilayah Indonesia maka ada satu hal yang tetap perlu menjadi perhatian dan pertanyaan mendasar adalah apakah perbankan dan unit-unit pembiayaan syariah tersebut telah menerapkan prinsip syariah secara benar. Hal ini setidaknya menjadi dasar perenungan awal atau kasar mengingat masih cukup banyak bank yang memiliki unit layanan

1 Halim Alamsyah, "Perkembangan dan Prospek Perbankan Syariah Indonesia: Tantangan Dalam Menyongsong MEA2015”, Makalah yang disampaikan dalam Ceramah Ilmiah Ikatan Ahli Ekonomi Islam (IAEI), Milad ke-8, Jakarta, 2012 
Prinsip Kesyariahan dalam Pembiayaan Syariah

perbankan syariah tetapi bisnis intinya tetap mengandalkan layanan perbankan konvensional (non syariah). Karenanya atas kondisi ini sejumlah pihak mempertanyakan dinamika perkembangan perbankan syariah di Indonesia yang begitu menggairahkan ini sebenarnya lebih merupakan fenomena apa?

Satu hal harus dijaga atas wacana ini adalah tetap mengkritisi dengan nilai-nilai ukuran kebenaran. Oleh karena itu hal yang paling obyektif dan mendasar agar kebenaran itu tetap terjaga adalah dengan melakukan analisis prinsip kesyariahan dari layanan pembiayaan yang berbasis syariah. Dalam makalah ini penulis ingin membahas prinsip-prinsip nilai dan dasar yang harus dipenuhi dalam menjalankan atau melaksanakan kegiatan pembiayaan berbasis syariah.

\section{Konsep dan Prinsip Dasar Ekonomi Islam}

Agama Islam memiliki konsepsi nilai sebagai dasar kebenaran yang mengatur semua bidang kehidupan manusia secara komprehensif dan universal, baik itu dalam hubungan vertikal dengan Sang Pencipta (habl min Allāh) maupun hubungan secara horizontal sesama manusia (habl min an-nās). Adapun tiga nilai dalam ajaran Islam tersebut meliputi :

1. Akidah: komponen ajaran Islam yang mengatur tentang keyakinan atas keberadaan dan kekuasaan Allah sehingga harus menjadi keimanan seorang muslim manakala melakukan berbagai aktivitas dimuka bumi semata-mata untuk mendapatkan keridlaan Allah sebagai khalifah yang mendapat amanah dari Allah.

2. Syariah: komponen ajaran Islam yang mengatur tentang kehidupan seorang muslim baik dalam bidang ibadah (habluminAllah) maupun dalam bidang muamalah(hablumminannas) yang merupakan aktualisasi dari akidah yang menjadi keyakinannya. Sedangkan muamalah sendiri meliputi berbagai bidang kehidupan antara lain yang menyangkut ekonomi atau harta dan perniagaan disebut muamalah maliyah.

3. Akhlak: landasan perilaku dan kepribadian yang akan mencirikan dirinya sebagai seorang muslim yang taat berdasarkan syariah dan aqidah yang menjadi pedoman hidupnya sehingga disebut memiliki akhlaqul karimah 
sebagaimana hadis Nabi saw yang menyatakan, "Tidaklah aku diutus kecuali untuk untuk menyempurnakan akhlak mulia”.

Dari ketiga nilai tersebut, di dalam Islam terdapat cukup banyak ketentuan yang menjadi acuan dalam melakukan kegiatan ekonomi antara lain meliputi sebagai berikut: ${ }^{2}$

- Islam menempatkan fungsi uang semata-mata sebagai alat tukar, bukan sebagai komoditas yang diperdagangkan apalagi untuk kegiatan spekulatif.

- Riba dalam segala bentuknya dilarang bahkan dalam ayat al-Qur'an tentang pelarangan riba yang terakhir yaitu surah al-Baqarah [2]:278-279 secara tegas dinyatakan sebagai berikut:

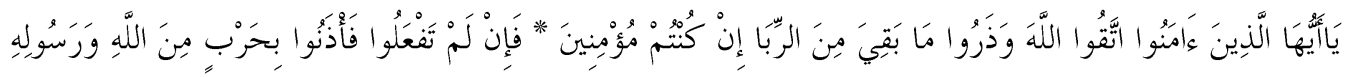

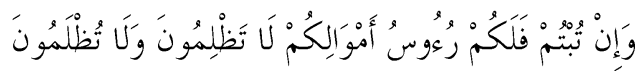

"Hai orang-orang yang beriman takutlah kepada Allah dan tinggalkanlah sisa-sisa riba itu jika kamu orang beriman. Kalau kamu tiada memperbuatnya ketahuilah ada peperangan dari Allah dan RasulNya terhadapmu dan jika kamu bertobat maka untukmu pokok-pokok hartamu. kamu tidak menganiaya dan tidak pula teraniaya."

- Harta harus berputar (diniagakan) sehingga tidak boleh hanya berpusat pada segelintir orang dan Allah sangat tidak suka terhadap orang yang menimbun harta sehingga tidak produktif dan oleh karenanya bagi mereka yang mempunyai harta yang tidak produktif akan dikenakan zakat yang lebih besar dibanding jika diproduktifkan. Hal ini juga dilandasi ajaran yang menyatakan bahwa kedudukan manusia dibumi sebagai khalifah yang menerima amanah dari Allah sebagai pemilik mutlak segala yang terkandung didalam bumi dan tugas manusia untuk menjadikannya sebesar-besar kemakmuran dan kesejahteraan manusia.

- Bekerja dan atau mencari nafkah adalah ibadah dan wajib dilakukan sehingga tidak seorangpun tanpa bekerja -yang berarti siap menghadapi resiko- dapat memperoleh keuntungan atau manfaat (bandingkan dengan

${ }^{2}$ Ahmad Baraba, Prinsip Dasar Operasional Perbankan Syariah, Jakarta: Bank Indonesia, 1999 
Prinsip Kesyariahan dalam Pembiayaan Syariah

perolehan bunga bank dari deposito yang bersifat tetap dan hampir tanpa resiko).

- Dalam berbagai bidang kehidupan termasuk dalam kegiatan ekonomi harus dilakukan secara transparan dan adil atas dasar suka sama suka tanpa paksaan dari pihak manapun.

\section{Fungsi Bank Dalam Prinsip Syariah}

Fungsi Bank dalam konsepsi syariah menurut Muhamad Syafi'i Antonio meliputi: fungsi bank syariah sebagai manajemen investasi, fungsi bank syariah sebagai investasi, fungsi bank syariah sebagai jasa-jasa keuangan, dan fungsi bank syariah sebagai jasa sosial. ${ }^{3}$ Keempat fungsi bank tersebut diatas apabila diuraikan secara operasional adalah :

- Sebagai penerima amanah untuk melakukan investasi atas dana-dana yang dipercayakan oleh pemegang rekening investasi/deposan atas dasar prinsip bagi hasil sesuai dengan kebijakan investasi bank.

- Sebagai pengelola investasi atas dana yang dimiliki oleh pemilik dana/sahibul mal sesuai dengan arahan investasi yang dikehendaki oleh pemilik dana (dalam hal ini bank bertindak sebagai manajer investasi)

- Sebagai penyedia jasa lalu lintas pembayaran dan jasa-jasa lainnya sepanjang tidak bertentangan dengan prinsip syariah

- Sebagai pengelola fungsi sosial seperti pengelolaan dana zakat dan penerimaan serta penyaluran dana kebajikan (fungsi optional)

\section{Aspek Kelembagaan Bank Dalam Prinsip Syariah}

Pengertian syariah (UU No. 10/1998) adalah aturan perjanjian berdasarkan hukum Islam antara bank dan pihak lain untuk penyimpanan dana dan atau pembiayaan kegiatan usaha atau kegiatan lainnya yang dinyatakan sesuai dengan syariah. Sedangkan perbankan syariah adalah sistem pelayanan perbankan yang berdasarkan syariah (hukum) Islam. Dimana untuk memulainya perlu dilandasi sebuah kesepakatan (akad) yang merupakan

${ }^{3}$ Muhammad Syafi'i Antonio, Bank Syariah: Dari Teori ke Praktik, Jakarta: Gema Insani Press, 
keterikatan antara bank syariah dan nasabahnya yang merupakan dasar untuk melakukan transaksi di bank syariah.

Akad keterikatan yang dimaksud dalam prinsip syariah disini adalah menempatkan posisi bank syariah dan nasabah bank syariah dalam relasi azas kemitraan, keadilan, dan transparan, bukan relasi antara peminjam dan pemberi pinjaman. Selanjutnya berangkat dari prinsip ekonomi berdasarkan Islam dan azas kemitraan maka transaksi perbankan syariah harus memenuhi sejumlah unsur sebagai berikut :

1. Tidak mengandung unsur riba.

2. Tidak mengenal konsep "time-value of money"

3. Tidak memiliki potensi mencelakai/membahayakan pihak lain maupun diri sendiri,

4. Tidak ada unsur penipuan (gharār)

5. Tidak ada unsur judi (maisir).

\section{Prinsip Produk Layanan Perbankan Syariah}

Secara umum produk jasa layanan perbankan terdiri atas kegiatan penghimpunan dana dan penyaluran dana (kredit). Hal yang sama juga dilakukan oleh bank syariah dimana terdapat produk giro, tabungan dan deposito untuk layanan simpanan dan produk pembiayaan untuk layanan penyaluran dana. Perbedaan mendasar produk-produk layanan perbankan syariah bila dibandingkan dengan bank konvensional adalah terletak pada prinsip ketentuan yang ditetapkan.

Dalam sistem syariah kegiatan penghimpunan dana menerapkan prinsip Wadiah dan pinsip Mudharabah. Sementara untuk penyaluran dana menganut prinsip Jjual Beli dan prinsip Bagi Hasil. Uraian analisa dari prinsip-prinsip produk layanan perbankan syariah adalah sebagai berikut.

\section{a) Penghimpunan Dana}

1. Prinsip Wadìah dalam produk giro dan tabungan adalah akad titipan murni dari pihak pemilik barang/dana kepada pihak penerima kepercayaan untuk menjaga keselamatan, keamanan dan keutuhan. Dalam prinsip ini : (1) pihak yang menerima titipan tidak boleh 
Prinsip Kesyariahan dalam Pembiayaan Syariah

menggunakan dan memanfaatkan uang atau barang yang dititipkan. (2) pihak penerima titipan dapat membebankan biaya kepada penitip sebagai penitipan. Aplikasi dalam perbankan syariah adalah simpanan giro wadi'ah dan tabungan wadiah dengan ketentuan: (1) sifatnya merupakan simpanan, (2) simpanan bisa diambil kapan saja (on call) atau sesuai kesepakatan, (3) tidak ada imbalan yang dari bank yang dipersyaratkan kecuali dalam bentuk pemberian (athāya) yang bersifat sukarela dari bank. Namun apabila berdasarkan kewenangannya prinsip Wadiah dibedakan dalam 2 jenis yaitu menjadi wadi'ah yad dhamānah yang berarti penerima titipan berhak mempergunakan dana/barang titipan untuk didayagunakan tanpa ada kewajiban penerima titipan untuk memberikan imbalan kepada penitip dengan tetap pada kesepakatan dapat diambil setiap saat diperlukan, sedang di sisi lain wadiah yad amānah tidak memberikan kewenangan kepada penerima titipan untuk mendayagunakan barang/dana yang dititipkan.

2. Prinsip Mudhārabah dalam produk tabungan dan deposito adalah akad penyimpanan dana dengan nisbah yang disepakati pada awal akad untuk bagi hasilnya. Dalam prinsip ini (1) nasabah bertindak sebagai șähib al-māl atau pemilik dana dan bank bertindak sebagai mudhärib atau pengelola dana, (2) bank dapat melakukan berbagai macam usaha yang tidak bertentangan dengan prinsip syariah dan mengembangkannya termasuk didalamnya mudhārabah dengan pihak lain, (3) modal harus dinyatakan dengan jumlahnya, dalam bentuk tunai dan bukan piutang, (4) pembagian keuntungan harus dinyatakan dalam bentuk nisbah dan dituangkan dalam akad pembukaan rekening, dan (4) Mudhärib menutup biaya operasional tabungan/deposito dengan menggunakan nisbah keuntungan yang menjadi haknya. Prinsip Mudhärabah berdasarkan kewenangannya dibedakan 2 jenis yaitu mudhārabah mutlaqah dimana mudharib diberikan kewenangan sepenuhnya untuk menentukan pilihan investasi yang dikehendaki. Berdasarkan prinsip ini tidak ada pembatasan bagi bank dalam menggunakan dana yang dihimpun. Sedangkan jenis yang lain adalah mudhärabah muqayyaddah dimana arahan investasi ditentukan oleh pemilik dana sedangkan mudharib bertindak sebagai pelaksana/pengelola. 


\section{b) Penyaluran Dana}

1. Pengertian prinsip Jual Beli di sini menekankan bahwa dalam perbankan syariah mengandung beberapa kebaikan, antara lain tujuan pembiayaan selalu diberikan kepada sektor riil karena yang menjadi dasar nilai adalah barang yang diperjual-belikan. Begitu juga dengan harga yang disepakati tidak berubah/tetap sampai akhir akad. Jenis prinsip jual beli terdiri atas Muräbahah, Salam dan Istishnä.

\section{Murābahah}

Adalah akad jual beli barang tertentu antara penjual dan pembeli dimana dalam transaksi jual beli tersebut penjual menyebutkan jenis barang yang akan dijual termasuk harga pembelian ditambah keuntungan yang diambil penjual Murābahah dapat dilakukan secara tunai dan secara angsuran. Secara operasional prinsip murabahah ini adalah bank membeli barang terlebih dahulu yang dibutuhkan nasabah dan menjual kepada nasabah sebesar harga pokok ditambah dengan keuntungan yang disepakati. Produk layanan perbankan syariah yang menerapkan prinsip ini adalah pembiayaan untuk keperluan investasi.

\section{Salam}

Adalah pembelian barang dengan penyerahan dilakukan kemudian setelah ada pembayaran di awal. Secara operasional prinsip salam adalah : (1) akad jual beli barang pesanan (muslam fib) antara pembeli (muslam) dengan penjual (muslam ilaib), (2) spesifikasi (jenis, macam ukuran, jumlah, mutu) dan harga barang disepakati diawal akad dan pembayaran dilakukan dimuka secara penuh, (3) apabila bank bertindak sebagai pembeli, kemudian memesan kepada pihak lain untuk menyediakan barang (Salam Paralel). Produk layanan perbankan syariah dengan prinsip Salam adalah untuk produksi agribisnis atau industri sejenis lainnya.

\section{Istishna}

Adalah akad pembelian barang melalui pesanan dan diperlukan proses untuk pembuatannya sesuai dengan pesanan pembeli dan pembayaran dilakukan di muka sekaligus atau secara bertahap. Jadi perbedaan dengan 
Prinsip Kesyariahan dalam Pembiayaan Syariah

Salam hanya pada metode pembayarannya. Salam pembayarannya harus dimuka sedangkan Istișna tidak harus di muka.

\section{Prinsip Bagi Hasil}

Adalah akad bersama kegiatan usaha yang didalamnya diperjanjikan adanya pembagian hasil atas keuntungan yang akan didapat antara kedua belah pihak atau lebih. Jenis bagi hasil terdiri atas Mudhärabah dan Musyarakah.

\section{$\checkmark$ Mudhārabah}

Akad antara pemilik modal dan pengelola modal untuk memperoleh keuntungan dengan kesepakatan bahwa pembagian hasil keuntungan dibagi sesuai nisbah yang disepakati awal akad. Prinsip pembagian hasil usaha adalah revenue sharing atau profit sharing. Secara operasional pemilik modal di sini adalah bank dan pengelola modal adalah nasabah.

\section{$\checkmark$ Musyārakah}

Akad untuk usaha patungan untuk membiayai usaha yang halal dan produktif. Pembayaran kembali atas dana dari pihak-pihak yang terlibat dalam pembiayaan proyek tersebut berikut bagi hasil yang disepakati dapat dilakukan secara bertahap ataupun sekaligus setelah proyek selesai. Produk layanan perbankan syariah yang sesuai prinsip musyärakah adalah pembiayaan proyek.

\section{Tabel 2.}

Perbedaan Bank Syariah dan Bank Konvensional

\begin{tabular}{|l|l|l|}
\hline & \multicolumn{1}{|c|}{ Bank Syariah } & Bank Konvensional \\
\hline $\begin{array}{l}\text { Fungsi dan Kegiatan } \\
\text { Bank }\end{array}$ & $\begin{array}{l}\text { Manajer Investasi, } \\
\text { Investor, Sosial, Jasa } \\
\text { Keuangan }\end{array}$ & $\begin{array}{l}\text { Intermediary Unit, } \\
\text { Jasa Keuangan }\end{array}$ \\
\hline $\begin{array}{l}\text { Mekanisme dan Obyek } \\
\text { Usaha }\end{array}$ & $\begin{array}{l}\text { Maisir, Gharär, Riba, } \\
\text { Bathil Dilarang }\end{array}$ & $\begin{array}{l}\text { Maisir, Gharär, Riba, } \\
\text { Bathil Tidak Dilarang }\end{array}$ \\
\hline $\begin{array}{l}\text { Hubungan } \\
\text { Nasabah }\end{array}$ & Kemitraan & Pinjam Meminjam \\
\hline
\end{tabular}




\section{Prinsip Organisasi Perbankan Syari'ah}

Salah satu prinsip yang harus mutlak ada di dalam organisasi perbankan syariah adalah terdapatnya Dewan Pengawas Syariah (DPS) dalam struktur organisasinya. Karena tugas dari DPS adalah mengawasi kegiatan usaha bank agar tidak menyimpang dari ketentuan atau prinsip syariah yang telah difatwakan. Fungsi Dewan Pengawas Syariah adalah :

1. Sebagai penasehat dan pemberi saran pada direksi, unit usaha syariah dan pimpinan kantor cabang syariah mengenai hal-hal yang berkaitan dengan syariah

2. Sebagai mediator antara bank dan pihak-pihak terkait dalam mengkomunikasikan usul dan saran pengembangan bank syariah.

3. Sebagai perwakilan dalam forum Dewan Syariah Nasional

\section{Penegakan Prinsip Syariah dalam Praktek Perbankan Syariah}

Seperti halnya pada bank konvensional salah satu bentuk perlindungan kepada nasabah, Bank Indonesia (sekarang OJK) membuat ketentuan tentang indikator penilaian kesehatan bank. Hal yang sama pun juga berlaku pada perbankan syariah. Namun diluar indikator teknis tentang ukuran kesehatan bank tersebut ada satu hal pokok yang harus dipenuhi terlebih dahulu dalam praktek perbankan syariah yaitu apakah terdapat penerapan kesyariahan yang sesuai menurut hukum Islam. Aspek ini untuk melindungi nasabah (masyarakat) mengingat prosentase terbesar nasabah perbankan syariah adalah memang masyarakat yang berniat menggunakan jasa layanan perbankan berbasis syariah.

Analisa prinsip-prinsip syariah dalam praktek perbankan syariah merupakan upaya penulis untuk memberikan edukasi tentang bagaimana karakteristik dari perbankan/lembaga keuangan syariah yang sesuai menurut hukum Islam. Hal ini diharapkan dapat menjadi panduan teknis karena ada perbedaan yang sangat mendasar dibandingkan dengan praktek perbankan konvensional. Lebih dari itu apabila pemahaman tentang pengetahuan prinsipprinsip praktek perbankan syariah telah melembaga, masyarakat dapat menjadi bagian dari kelompok pendorong agar perbankan/lembaga syariah dapat 
Prinsip Kesyariahan dalam Pembiayaan Syariah

menerapkan good corporate governance (tata kelola bank) sebagai wujud jaminan dan keamanan atas kualitas layanan.

Karena dari sisi masyarakat sebagai pengguna jasa layanan berkeyakinan penuh bahwa dalam konsepsi perbankan syariah terdapat nilai-nilai :

1. Islam memandang harta yang dimiliki oleh manusia adalah titipan/amanah Allah SWT sehingga cara memperoleh, mengelola dan memanfaatkannya harus sesuai ajaran Islam,

2. Bank syariah mendorong nasabah untuk mengupayakan pengelolaan harta nasabah (simpanan) sesuai ajaran Islam

3. Bank syariah menempatkan karakter/sikap baik nasabah maupun pengelolaan pada posisi yang sangat penting dan menempatkan sikap akhlakul karimah sebagai sikap dasar hubungan antara nasabah dan bank

4. Ikatan emosional yang kuat didasarkan prinsip keadilan, prinsip kesederajatan dan prinsip ketentraman antara Pemegang Saham, Pengelola Bank dan Nasabah atas jalannya usaha bank syariah

Sementara dari sisi bank, bahwa agar keyakinan nasabah ini direspon sebagai pemberian amanah maka kualitas sumber daya manusia yang terlibat dalam operasional perbankan syariah maka harus memiliki kualifikasi yang shidiq (benar dan jujur), tabligh (mengembangkan lingkungan/bawahan menuju kebaikan), amänah (dapat dipercaya), fathänah (kompeten dan profesional) dan memiliki komitmen dalam pengembangan SDM secara berkelanjutan.

\section{Penutup}

Aspek lain yang perlu menjadi pencermatan guna mengetahui apakah satu bank syariah telah menerapkan prinsip kesyariahan secara benar adalah dengan mencermati prinsip dasar akuntansi yang digunakan. Sebagaimana dalam produk dan skema jasa layanannya, prinsip akuntansi antara perbankan syariah dan perbankan konvensional juga berbeda. Perbankan syariah menerapkan prinsip dasar akuntansi bank Islam. Hanya saja pemahaman soal pengetahuan ini merupakan pengetahuan yang bersifat sangat teknis sekali dimana tidak semua masyarakat awam bisa memahaminya. Bagi masyarakat yang ingin mengetahui satu bank syariah tertentu sudah menerapkan prinsip 
dasar akuntansi bank Islam dapat dilihat dari laporan keuangannya untuk kemudian dikonsultasi kepada yang dapat membaca, menganalisa, memahami dan memberikan penilaian. Untuk memperoleh laporan keuangan dari bank syariah tertentu masyarakat dapat mengakses secara on line melalui layanan informasi yang disediakan oleh OJK, atau melihatnya di papan informasi di kantor bank syariah yang dimaksud.

Upaya edukasi tentang aspek teknis prinsip dasar akuntansi bank Islam memang tidak bisa dilakukan secara generik karena untuk memahaminya perlu pendidikan khusus. Meskipun demikian hal ini bukan berarti menjadi kendala masyarakat untuk mengurungkan niatnya mengakses jasa layanan perbankan syariah. Beberapa hal yang tetap dan harus menjadi penekanan dalam mengakses jasa layanan perbankan syariah adalah:

1. Bank tersebut tidak menempatkan uang sebagai komoditas yang diperdagangkan

2. Bank tersebut tidak menerapkan suku bunga atas balas jasa layanan pembiayaan, tetapi dengan bagi hasil atau nisbah marjin yang disepakati di awal

3. Adanya akad sebagai bentuk keterikatan berdasarkan azas kemitraan, keadilan, dan transparan,

4. Tidak mengenal konsep "time-value of money"

5. Tidak memiliki potensi mencelakai/membahayakan pihak lain maupun diri sendiri,

Jika kelima karakteristik tersebut diyakini ada dan telah diterapkan, Insya Allah bank tersebut sudah menerapkan prinsip dasar akuntansi bank Islam. 
Prinsip Kesyariahan dalam Pembiayaan Syariah

\section{DAFTAR PUSTAKA}

Alamsyah, Halim, "Perkembangan dan Prospek Perbankan Syariah Indonesia: Tantangan Dalam Menyongsong MEA2015", Makalah yang disampaikan dalam Ceramah Ilmiah Ikatan Ahli Ekonomi Islam (IAEI), Milad ke-8, Jakarta, 2012

Anshori, Abdul Ghofur, Perbankan Syariah di Indonesia, Yogyakarta: Gadjah Mada University Press, 2007

Antonio, Muhammad Syafi'i, Bank Syariab: Dari Teori ke Praktik, Jakarta: Gema Insani Press, 2001

Arifin, Zainul, Konsep Operasional Bank Syariah, Jakarta: Rafa Consulting.

Bank Indonesia, Statistik Perbankan Syariah - Agustus 2013, Jakarta: Bank Indonesia, 2013

Baraba, Ahmad, Prinsip Dasar Operasional Perbankan Syariah, Jakarta: Bank Indonesia, 1999

Puspitaningsih, Dewi, "Analisis Aplikasi Prinsip-Prinsip Perbankan Syariah Terhadap Aspek Penghimpunan Dana dan Aspek Penyaluran Dana (Studi Kasus Pada Bank Muamalat Indonesia Cabang Malang)", Skrispsi, Malang: Fakultas Ekonomi Universitas Malang, 2010

------, "Konsep dan Sistem Perbankan Syariah"

http://file.upi.edu/Direktori/FPEB/PRODI._MANAJEMEN_FPEB/BUD

HI_PAMUNGKAS_GAUTAMA/KONSEP_DAN_SISTEM_PERBANKA

N_SYARIAH.pdf, diakses 25 Mei 2015 